\title{
Montessori Yaklaşımı Temelli STEM Etkinliklerinin Okul Öncesi Öğretmen Adaylarının Yaratıcılık Becerilerine Etkisi
}

\author{
Zehra Çakır ${ }^{1 *}$ \\ Doç. Dr. Sema Altun Yalçın² \\ Prof. Dr. Paşa Yalçın ${ }^{3}$
}

Geliș tarihi: 02.04.2019

Kabul tarihi: 07.05.2019

\section{Atıf bilgisi:}

Uluslararası Bilimsel

Araştırmalar Dergisi (IBAD)

Cilt: $4 \quad$ Sayı: 2

Sayfa: 392-409 Yll: 2019

Dönem: Yaz

This article was checked by Turnitin Similarity Index 35\%

\footnotetext{
${ }^{1 *}$ Erzincan Binali Yıldırım Üniversitesi, Türkiye, zehracakir.29@hotmail.com, ORCID ID 0000-0003-4585-8214

2 Erzincan Binali Yıldırım Üniversitesi, Türkiye, saltun_11@hotmail.com ORCID ID 0000-0001-6349-2231

${ }^{3}$ Erzincan Binali Yıldırım Üniversitesi, Türkiye, pasayalcin@hotmail.com ORCID ID 0000-0002-8085-7914
}

\begin{abstract}
öz
$\mathrm{Bu}$ araştırma, Montessori yaklaşımı temelli STEM etkinliklerinin okul öncesi öğretmen adaylarının; yaratıcılık becerilerinin gelișimleri üzerinde bir etkisinin olup olmadığını tespit etmek amacıyla yapılmıştır. Araştırmada karma yöntem kullanılmıştır. Araştırma örneklemini 2017-2018 eğitim öğretim y1lında Devlet Üniversitesinin Eğitim Fakültesi Okul Öncesi Öğretmenliği Bölümünde öğrenim gören 50 öğretmen adayı oluşturmuştur. Araştırmada öğretmen adaylarının yaratıcılık becerilerindeki değişimi belirlemek amacıyla tek gruplu öntest sontest deseni olușturulmuştur. Araştırma süresince elde edilen nicel verilerin analizi istatistiksel yöntemler ile nitel verilerin analizi ise içerik analizi ile yapılmıştır. Araştırmada nicel verilerin elde edilmesinde "Ne Kadar Yaratıcısınız?" ölçeği ile "Yarı yapılandırılmış mülakat formu" kullanılmışıır. Nicel verileri destekleyici nitelikte hazırlanan nitel veriler açık uçlu yarı yapılandırılmış görüşme formundan oluşmaktadır. 14 hafta boyunca adaylara Montessori yaklaşımı temelli STEM eğitimleri verilmiştir. Araştırma sonucunda elde edilen bulgularda; yaratıcıllk becerilerinin öntest ve sontest puanları arasında, anlamlı bir farklılık olduğu ve nitel verilerden elde edilen sonuçların da nicel verileri destekler nitelikte olduğu bulunmuştur.
\end{abstract}

Anahtar Kelimeler: Montessori yaklaşımı, Okul öncesi öğretmen adayları, STEM, Yaratıcilik 


\title{
Investigation of the Effects of Pre-School Teacher Candidates Creativity Skills on
} Montessori Approach Based STEM Effectiveness

\author{
Zehra Çakır ${ }^{1 *}$ \\ Assoc. Prof. Dr. Sema Altun Yalçın² \\ Prof. Dr. Paşa Yalçın ${ }^{3}$
}

First received: 02.04 .2019

Accepted: 07.05.2019

\section{Citation:}

Journal of the International

Scientific Research (IBAD)

Volume: $4 \quad$ Issue: 2

Pages: 392-409 Year: 2019

Session: Summer

This article was checked by Turnitin. Similarity Index 35\%

1* Erzincan Binali Yıldırım University, Turkey, zehracakir.29@hotmail.com, ORCID ID 0000-0003-4585-8214

2 Erzincan Binali Yıldırım University, Turkey, saltun_11@hotmail.com ORCID ID 0000-0001-6349-2231

${ }^{3}$ Erzincan Binali Yıldırım University, Turkey, pasayalcin@hotmail.com ORCID ID 0000-0002-8085-7914

* Corresponding Author

\begin{abstract}
This research aims to determine whether STEM practises- Montessori- based Approach have any effects of pre-school trainee teachers on creativity abilities to provide development. Mixed method has been used in this research. This study has been carried out fifty trainee teachers studying Pre-school Teaching in State University Education Faculty during 2071-2018 academic year. To detect the alteration of creativity abilities of the teacher trainees, one group pretest posttest experimental desing has been formed in this study. During the research, the analyzing of the quantitative data having been acquired has been carried out by means of statistical methods. In addition, the analyzing of teh qualitative data has been carried out with content analysis. In this study, to get data "How Creative Are You?" scales and semi-structured interview form has been used. The qualitative data prepared by a research having a wuality supporting the quantitative data has been occured open-ended semi-structured interview form. STEM trainings Montessori based approach have been given for fourteen weeks. As a result of the research; It was found that there was a significant difference between the pre-test and post-test scores of the creativity skills and the quantitative data.
\end{abstract}

Keywords: Creativity, Montessori approach, Preschool teacher candidates, STEM 


\section{GİRIŞ}

Çocuklar dünyaya doğuștan doğal bir merak ve keşfetme duygusu ile gelirler (Eratay, 2009). Çocukların bu doğal meraklarını bilimsel süreçler becerileri ile kullanabilmesi, daha fazla bilimsel etkinlik yapabilmesi ve geleceğin 21. yy becerilerine sahip kaliteli birer birey olabilmeleri için kendilerine yol gösterecek alanında uzman rehberlere gereksinim duyulmaktadır. Doğru rehberlik sunulduğunda çocuklar özellikle fen alanına yönelik olumlu yaşantılar elde edebilmektedirler. Bu sebeple temel seviye olan okul öncesi eğitimler ve bu alanda yetișen okul öncesi öğretmenlerinin rolü oldukça önemlidir (Koyunlu Ünlü ve Dere, 2018). Günümüzde ülkelerin kalkınmasında ve rekabete dayalı ekonomik işs gücünde, problemlere çözüm üreten ve yaratıcılık becerileri gelişmiş kaliteli bireylerin yetişmesi bakımından eğitim ortamları daha da önem kazanmıştır (Yuvacı ve Dağlığlu, 2018). Bu sebeple öğrencilere bilginin nasıl elde edileceğini, bunları nasıl değerlendirecekleri, bir problemi çözmek için bu bilgiyi nasıl kullanacakları ve yaratıcılık eğitimlerine dair bilgiler erken çocukluk döneminde verilmeye başlanması gerekmektedir (Van Till et al., 1997). Problem çözme, var olan bir sorunun cevabını planlama, güç bir görevi başarmayı sağlayacak durum ya da karşı1ık sunma, bir olanak önerme veya ilgi göstermedir (İșmen, 2001). Wallas (1926) yaratıcılığı, herhangi bir problem çözme süreci olarak tanımlamaktadır. Bireyin orijinal, üretken, farklı ve nitelikli düşünebilmesine ve ileride sağlam adımlar atarak sorumluluk bilincine sahip bireyler olmasına yardımcı olan ortamlardan biri eğitim ortamıdır (Yuvacı ve Dağlığlu, 2018). 21. yy bireylerinin sahip olması gereken problem çözme, eleştirel düşünme ve yaratıcılık becerilerinin erken yaşlarda kazandırılmasında Montessori yaklaşımı (Durakoğlu, 2011) ve STEM eğitiminin etkili olduğu yapılan birçok çalışmada desteklenmiştir (Uyanık Balat ve Günşen, 2017). Montessori yaklaşımı, Maria Montessori tarafından çocuğun kendi kendine uygulayarak en iyi ve en kolay şekilde öğrenmeyi gerçekleştirme üzerine kurulmuştur (Kuşçu vd., 2014). Montessori yaklaşımındaki amaçlar; çocuğun özgüven, inisiyatif, ne istediğini bilme ve bunu uygulama, bağımsız hareket edebilme, problem çözme, eleştirel analizler yapabilme, yaratıcılık becerilerini kullanabilme, yoğunlaşma, düzenli olma, yardımlaşma ve başkalarına saygı duyma yetilerini geliştirmektir. $\mathrm{Bu}$ amaçlara ulaşabilmek için ise ilk olarak, çocuğun öğrenme keyfini zorlamadan kendi kendine yaşamasını ve öğrenmeyi istemesini sağlamak; ikinci olarak ise öğrenme mekanizmasını mükemmelleştirmeye yardımcı olabilmektir (Özdağ, 2014). Montessori yaklaşımı, çocukları etkinliklere isteyerek katılması için güdülemeye, tekrarlamalı somut deneyimler aracıllğıyla yeteneklerini geliştirmeye cesaretlendirmektedir. Çocukları, akranları ile birlikte öğrenmelerini ve sosyal etkileşim ile işbirliği yaparak öğrenmeye teşvik etmektedir. Montessori yaklaşımı, bireye problem çözme ve zihinsel gelişim için duyu eğitimi, yaratıcı ifade için öğrenme etkinlikleri sağlamaktadır. Montessori yaklaşımını diğer yaklaşımlardan farklı kılan en önemli özellikleri arasında, yaklaşımın kurucusu tarafından geliştirilmiş kendine has materyallerinin olması, etkinliklerin çocukların katılımlarıyla ve eylemleri ögrenmelerine firsat vermesidir. Bu materyaller yardımıyla uygulanan Montessori yaklaşımı, fiziksel ve ruhsal açıdan çocuğu olumlu yönde etkileyerek; çocuğun her türlü duyu, hareket ve dil eğitimine önem vererek; bedensel, sosyal, duygusal açılardan gelişimlerine önemli katkılar sağlamaktadır (Dereli, 2017).

STEM Eğitimi ise; ABD, Japonya, G. Kore, Almanya ve Çin gibi ülkelerde mevcut olan ekonomi ve teknoloji güçlerini korumak ve geliştirmek amaciyla ortaya çıkan Science (Fen), Technology (Teknoloji), Engineering (Mühendislik) ve Mathematics (Matematik) kelimelerinin ingilizce baş harflerinin kısaltılmasıyla oluşan bir eğitim sistemidir. Bu disiplinlerin kısaltılması ilk olarak Judith A. Ramaley tarafindan kullanılmış olsa da temeli 19. yyda lider ülkelerin birbirleriyle ekonomik rekabetleri sonucu ortaya çıkmıştır (Breiner et al., 2012). STEM eğitiminin kalbindeki kavramları merak, yaratıcılık, işbirliği ve eleştirel düşünme şeklinde tanımlayan Chesloff (2013), STEM eğitiminin okul öncesi döneminde başlaması gerektiğini savunmaktadır. Okul öncesi dönemden itibaren çocuklara STEM deneyimi kazandırılması, gelecekte bireylerin karşılaşacakları karmaşık problemlere çözümler üretebilmelerini ve ekonomik anlamda önemli katkı sağlayacağı belirtilmektedir. Amerika Ulusal Araştırma Konseyi, başarılı bir STEM eğitimi için, okul öncesi dönemden itibaren başlamanın önemini vurgulamıştır (Uğraş, 2017). Dolayısıyla bunun gerçekleşmesi için öncelikle STEM alanında uzman okul öncesi öğretmenlerinin yetiştirilmesi gerekmektedir (Koyunlu Ünlü ve Dere, 2018). Bybee (2010), STEM eğitimini, okul öncesinden 12'nci sınıfa kadar matematik, bilim tabanlı mühendislik ve teknolojiyi entegre ederek öğreten bir yaklaşım şeklinde ifade etmiştir. Ülkelerin çeşitli ihtiyaçları ve gelişmişlik düzeylerine bağlı olarak dünyada tek bir tanımı olmayan STEM kavramı (Çolakoğlu ve Günay Gökben, 
2017), Türkiye' de fen bilgisi, teknoloji, matematik ve mühendislik yani FeTeMM eğitimi olarak (Akgündüz ve Akpınar, 2018; Çorlu, 2014); bilim, teknoloji, mühendislik ve matematik (BTMM) eğitimi olarak (Adıgüzel, Ayar, Çorlu ve Çorlu, 2012) çeşitli araştırmacılar tarafindan ifade edilmektedir. Yıldırım ve Altun (2014) ise çalışmalarında STEM ifadesindeki 'Science' kelimesine 'Fen' değil 'Bilim' olarak yer verilmesinin daha uygun olacağını ifade etmektedirler. STEM eğitimine ilişkin farklı isimlendirmelere yönelik gereken literatür taraması yapılarak uluslarası bir eğitim sistemi olmas1 nedeniyle STEM olarak ifade edilmesi uygun görülmüştür (Altun Yalçın ve Yalçın, 2018). Koştur (2017)' a göre STEM; 21. yüzyılda ihtiyaç duyulan problem çözebilen, sorgulayan, analiz edebilen, üreten, yaratıcı ve kaliteli bireyleri yetiştirmek için ortaya çıkmış bir yaklaşımdır. Amerikan Ulusal Araştırma Konseyi'ne göre STEM eğitiminin temelinde üç amaç vardır; birincisi yükseköğretim kariyerlerinde STEM alanlarında devam edecek öğrenci sayısını arttırmak, ikincisi STEM iş gücüne katılımı yaygınlaştırmak ve üçüncüsü STEM okuryazarlığına sahip bireyler yetiştirmektir. STEM eğitiminin amacı öğrenmenin bütüncül bir yaklaşım içerisinde gerçekleştirilmesi için disiplinler arası ilişki kurabilmeyi sağlamaktır. STEM eğitimi, öğrencilerin problemlere disiplinler arası bakış açısıyla bakmasını, bütüncül bir eğitim yaklaşımıyla bilgi ve beceri kazanmasını amaçlar (Şahin vd., 2014). Öğrencilerin temel bilim derslerinde öğrendikleri bilgileri bütünleştirmelerini sağlayan STEM eğitimi dünyada birçok ülkenin öğretim programlarına dâhil edilmektedir. Böylelikle, teorik bilgi; uygulamaya, ürüne ve yenilikçi buluşlara dönüştürülmektedir (MEB, 2016). STEM eğitiminin Türkiye için çıkarımlarını Çepni (2017) araştırmasında; ülkemizin STEM eğitimine ilgisinin başlamasını, PISA ve TIMMS sınavlarında gösterilen öğrenci başarısızlığının sebepleri aranırken ve STEM' in öğretim programlarına nasıl uyarlanacağı, STEM' i sınıflarında uygulayabilen öğretmenlerin nasıl yetiştirileceği konuları üzerinde gerekli araştırmalar yapılmış ve yapılmaya devam edildiğini belirtmiştir. Aslan Tutak vd. (2017) çalışmalarının sonuçlarında; öğretmen adaylarının STEM eğitimi konusunda, üniversiteden mezun olmadan bilinçlendirilmelerinin gerekliliğini ifade etmiş, STEM' in disiplinler arası yaklaşım olması sebebiyle öğretmenlerin kendi alanları dışındaki alanlarda bilgi sahibi olmadıkları ve bu alanlarda da gereken bilgilerin verilmesi gerektiğini vurgulamıştır. Günümüzde okul öncesi dönemdeki çocuklar mühendis, problem çözücü, lider, bilim insanı, yaratıcı gibi devasa bir potansiyele sahip bireyler olarak ifade edilmektedir (Hadzigeorgiou, 2002). Birçok eğitimci, yaşamımızın ilk sekiz yılında edinilen deneyimlerin sonraki yaşantımızda karar verici olduğu görüşüne sahiptir (Kaya ve Gündüz, 2015; Katz, 2010). Dolayısıyla STEM eğitimine başlanması gereken en iyi dönemin "okul öncesi dönem" olduğu kabul edilmiştir (Çepni, 2017). Yine son zamanlarda, erken çocukluk döneminde verilen eğitim müfredatındaki teknoloji ve mühendislik giderek artan önemli bir nokta olmuştur. Robotik, bireylerin temelde erken çocukluk döneminde hem $\mathrm{T}$ (teknoloji) hem de $\mathrm{M}$ (mühendislik) kavramlarıyla uğraşmaları için somut ve eğlenceli bir yol sunmaktadır (Allen, 2016). Fen, teknoloji, mühendislik ve matematik ile ilgili konuların çocuklara okul öncesi dönemde aktarılması halinde, STEM'le ilgili ilerde olumlu kararlar alma olasılığını artırdığına dair kanıtlar bulunmaktadır (Diamond and Lee, 2011). Çepni (2017), Amerika' da yapılan araştırmalarda ilkokul düzeyinde STEM eğitimleri verilmeye başlandığında çocuklar üzerinde olumlu etkiler bıraktığını fakat ilerleyen dönemlerde meslek seçimlerinde bireylerin STEM alanlarını tercih etmediklerini ifade etmiştir. Bu da STEM eğitiminin daha temel seviye olan okul öncesi dönemde verilmesi gerekliliğini ortaya çıkarmış ve bu alan üzerinde çalışmalara başlanılmıştır (Çepni, 2017). Yüksek kaliteli hizmet içi ve hizmet öncesi Montessori yaklaşımı ve STEM eğitimi almış okul öncesi öğretmenlerinin sayısının arttırılması bireyi temelden yetiştirme açısından oldukça önemlidir (Açıkgöz, 2018). Açıkça ifade edilmelidir ki, eğitim fakültelerinde öğrenim gören öğretmen adaylarına, lisans eğitimi verilirken STEM eğitimi konusunda yetiştirilmeleri; gelecek meslek hayatlarında yetiştirecekleri öğrencilerin STEM alanlarına karşı olumlu tutumlar geliştirmeleri ve bu alanlarda meslek seçimlerinde bulunmaları açısından önem arz etmektedir (Çolakoğlu ve Günay Gökben, 2017). Bunu sağlayabilmenin en kolay yolu ise bireye STEM eğitimini çocukluk döneminde yapılan oyunlar yardımıyla gerçekleştirmektir (Uyanık Balat ve Günşen, 2017). STEM alanında yapılan eğitimlerin ise temelden yani okul öncesi dönemden, Montessori yaklaşımı ile birleştirilerek verilmesi öğrenmenin daha kolay ve kalıcı olmasını sağlayacaktır. Bu çalışmanın temel amacı, Montessori yaklaşımı temelli STEM etkinliklerinin okul öncesi öğretmen adaylarının; yaratıcılık becerilerinin gelişimleri üzerinde bir etkisinin olup olmadığını tespit etmektir. 


\section{YÖNTEM}

\subsection{Araştırma Modeli}

Çalışmada etkisi incelenen eğitimin etkililiğini birçok kanıtla desteklemek amacıyla karma yöntem kullanılmıştır. Creswell ve Tashakkori (2007); karma yöntemin en temel noktası hem nitel hem de nicel veri ve kaynaklarının toplanması, birleştirilmesi ve ilişkilendirilmesidir. Karma yöntem araştırması kendi içinde; açıklayıcı karma araştırma, çeşitleme karma araştırma ve keşfedici karma araştırma yöntemleri olmak üzere üçe ayrılmıştır (Creswell, 2002). Açıklayıcı desenlerde nicel araştırma baskındır ve araştırmacılar ilk önce nicel verileri toplayarak analiz ederler. Daha sonra bu verileri tamamlamak, desteklemek ve rafine edebilmek için nitel verileri toplarlar (Büyüköztürk vd., 2016). Çalışmada nicel analizin baskın olduğu açıklayıcı desen kullanılmıştır. Yani ilk olarak nicel veriler toplanarak analiz edilmiş daha sonra nicel sonuçlarımızı desteklemek ve tamamlamak amacıyla nitel veriler toplanarak analizi yapılmıştır. Nicel verilerin elde edilmesinde deneysel araştırma türlerinden biri olan zayıf deneysel desenin tek grup ön test son test düzeni oluşturulmuştur. $\mathrm{Bu}$ desene ihtiyaç duyulmasındaki temel neden, herhangi yeni bir öğrenme yöntemi veya programının etkililiğini ölçmek ve önerilerde bulunmaktır (Büyüköztürk, 2016).

\subsection{Araștırmanın Çalıșma Evreni ve Örneklemi}

Araştırmanın çalışma evrenini, Erzincan ilinde yer alan devlet üniversitesinde okul öncesi bölümü 3 . Sınıfta öğrenim gören öğretmen adayları oluşturmaktadır. Uygulamada çalışma evreninden örneklem seçimi seçkisiz atamayı içermeyen uygun örnekleme yöntemi kullanılarak yapılmıştır. Örneklem grubunda 50 öğretmen adayı ile çalışılmıştır. Çalışmada okul öncesi öğretmen adaylarına 14 hafta boyunca teorik ve uygulama olarak Montessori yaklaşımı temelli STEM etkinlikleri uygulatılmıştır. $\mathrm{Bu}$ etkinlikler; basit materyallerle, tiplerle, legolarla ve robotik, kodlama ile gerçekleştirilerek, öğretmen adayının kendi becerilerini geliştirebilecekleri ve öğrencilerine derste uygulatabilecekleri pek çok etkinlik ile zenginleştirilmiştir.

\subsection{Verilerin Toplanması}

Çalışmada, okul öncesi öğretmen adaylarının yaratıcılıklarını belirlemek amacıyla Whetton ve Cameron (2002) tarafından geliştirilen "How Creative are You? (Ne Kadar Yaratıcısınız?)" adlı ölçeğin Aksoy (2004) tarafından Türkçe uyarlaması yapılan formundan yararlanılmıştır. Aksoy (2004) tarafindan Türkçe'ye uyarlanan Yaratıcı Düşünce Ölçeği'nin güvenirlik ve geçerlilik (cronbach alfa değeri=0,94) çalışmaları yapılmıştır. Çalışma için ulaşılan cronbach alfa değeri ise 0,768 bulunmuştur. Yaratıcılık Ölçeği, öğretmen adaylarının sahip olduğu tutumlar, özellikler, değerler, güdüler ve ilgileri karakterize etmektedir. Ölçek 40 madde içermekte ve 3'lü likertten oluşmaktadır. Yaratıcılık Ölçeği'nde yer alan her bir madde için puanlama farklı olmuştur. Ölçekteki maddelerin sahip olduğu en az puan (-2), en yüksek puan 30 olmuştur. Bununla birlikte ölçekteki 40. soru bir derecelendirme ölçeği türünden değildir. 40. soru 'sizi en iyi yansıtan 10 kelimeyi seçiniz' şeklinde yaratıcılıkla ilgili 54 tane kimlik sıfatı verilmiş ve kişinin bunlardan kendine en uygun olan 10 kelimeyi seçmesi istenmiştir. Bu kelimelerin puan değerleri ölçekte 0-2 arasında değişmektedir. Çalışmada nitel verilerin toplanmasında ise araştırmacı tarafindan nicel veri araçlarının alt boyutları ve maddeleri dikkate alınarak adayların yaratıcılık becerilerinin gelişimine etkisini desteklemek amacıyla hazırlanmış yarı yapılandırılmış mülakat formu kullanılmıştır.

\subsection{Süreç}

Çalışmada uygulamalara geçilmeden önce alan taraması yapılmış, eğitim ortamlarının hangi felsefe ve uygulama yaklaşımları hedef alınarak öğrenme ortamlarının kullanıldığı araştırılmıştır. Yapılan taramalar sonucunda elde edilen veriler, öğrencilerin genellikle ne tür öğretim ortamlarından zevk aldıkları, hangi ortam ve etkinliklerin öğrenciler üzerinde olumlu etkiler bıraktığı, eğitim ortamlarından neler beklediklerini ve önceliklerinin neler oldukları yapılan literatür tarama sonuçları ile birleştirilmeye çalışılmıştır. Bütün bunların sonucunda belirlenen etkinliklerde okul öncesi öğretmen adaylarına teorik ders aşamasını çok uzatmadan sadece gerekli bilgileri kazandırıp içselleştirebilmeleri ve uygulamalarla bütünleştirebilmeleri amacıyla verilmiştir. Etkinlik ve uygulamaların seçiminde dikkat edilen bazı noktalar; uygulanan etkinliklerin STEM eğitimi özelliklerinin kesinlikle tam anlamıyla barındırması, karşılaşacakları problemlere yönelik sorunları kendi tecrübeleri ve bilgileri ile çözebilecekleri nitelikleri içermesi, öğretmen adaylarının alan bilgilerini kullanıp farklı ve yeni tasarımlar, ürünler 
oluşturabilecekleri heyecanını verebilecek özellikte olması, hem gelecek meslek hayatlarındaki öğretme ortamlarında hem de bireysel gelişimlerinde kullanabilecek düzeyde olmasına özellikle dikkat edilmiştir. Etkinlikler; atılmıs parçalardan yani günlük yaşamın her alanında bulunabilen basit malzemelerden, robotik-kodlama legolarından ve tiplerden oluşturulmuştur. Öğretmen adaylarına bir eğitim-öğretim dönemi boyunca alanında uzman araştırmacılar tarafından Montessori yaklaşımı temelli STEM etkinlikleri yaptırılmışıı. Toplamda 14 hafta süren bu uygulamalar araştırmacıların rehberliğinde gerçekleştirilmiştir. $\mathrm{Bu}$ eğitim süresince; adayların yaratıc1lık becerilerinin geliştirilmesine, birincil kaynaklardan bilgi elde edinebilmelerine, öğrendikleri bilgiler ile günlük yaşam durumları arasında bağ kurabilmelerine ve öğrendikleri bilgilerle bir şeyler inşa ederek kendi ürünlerini tasarlayabilmelerine yardımcı olmaya çalışılmıştır. Bu süreçte öncelikle adaylara STEM eğitimi ve Montessori yaklaşımı hakkında temel teorik bilgiler verilmiştir. Daha sonra dört kişiyi geçmeyen gruplar oluş̧urmaları ve her hafta önceden uzmanlar tarafından belirlenen etkinlikleri yapmaları istenmiştir. Gruplar oluşturulduktan sonra haftanın belirlenen etkinliği ile ilgili nasıl yapacaklarına dair önce kısa ve yeterli seviyede olacak şekilde teorik bilgiler (etkinlik için gerekli olan fen ve matematik gerektiren bilgiler, yapılacak etkinliğin şeklinin çizimle gösterilmesi gibi bilgiler) anlatılarak gerekli malzemeler tanıtılmıştır. Daha sonra her grubun yapılacak etkinlik için hazırlanmış olan malzemelerden almaları ve kendilerine verilen sürede çalışmalarını tamamlamaları istenilmiştir. Uygulamalarda sırasıyla basit malzemeleri içeren etkinlikler, robotik kodlama ve tip çalışmaları yaptırılmıştır. Bütün etkinlikler bittikten sonra her grubun Montessori yaklaşımı temelli STEM etkinliklerine uygun olacak şekilde istedikleri bir konu üzerinde gerekli materyalleri ve etkinlikleri kendileri oluşturarak belirledikleri kazanımlar doğrultusunda sınıfta sunmaları istenilmiştir.

\section{BULGULAR ve YORUM}

\subsection{Verilerin Analizi ve Yorumlanması}

Çalışmada elde edilen nicel veriler istatistiksel yöntemlerle analiz edilmiştir. Analizlerde herhangi bir istatistiksel yönteme karar verebilmek için verilerin normal dağılım gösterip göstermediğinin belirlenmesi bakımından tüm ölçümlerin histogram grafiklerine, çarpıklık katsayısına ve Kolmogorov-Smirnov (örneklem sayısı 30' un üzerinde olduğu için bu test dikkate alınmıştır) testine bakılmış ve değerlerin normallik varsayımına uygun olduğu bulunmuştur ( $\mathrm{p}>, 05$; Can, 2016). Örneklem grubunun ön test ve son test yaratıcılık puanları arasında anlamlı bir farklılık gözlenip gözlenmediğini belirlemek amacıyla Bağımlı Örneklem t-Testi (Paired Sample t- Test) yapılmış ve sonuçlar Tablo 1' de gösterilmiştir. Bağımlı Örneklem t-Testi'nde aynı örneklem grubu üzerinde ön ve son test ortalamaları karşılaştırılmaktadır (Can, 2016; Büyüköztürk vd., 2016). T testine bakılmadan önce verilerin normal dağıldığı ve toplam puanların homojenliği sağladığı görülmüştür ( $\mathrm{p}>0,05$; Can, 2016)

Tablo 1. Yaratıcılık becerilerine ilişskin Bağımlı Örneklem t-Testi sonuçları

\begin{tabular}{lllllll}
\hline Ölçümler & $\mathbf{N}$ & $\overline{\boldsymbol{X}}$ & $\mathbf{S s}$ & $\mathbf{t}$ & $\mathbf{S d}$ & $\mathbf{P}$ \\
\hline Öntest & 50 & 46,20 & 7,89 & & & \\
Sontest & 50 & 65,96 & 8,23 & $-12,145$ & 49 &, 000 \\
\hline
\end{tabular}

$\mathrm{p}<, 05$

Okul öncesi öğretmen adaylarının yaratıcı eğilimlerinin ön ve son test puanları arasında yapılan Bağımlı Örneklem t-Testi sonuçları Tablo 1' de gösterilmiştir. Testin sonuçlarında uygulama öncesi puan ortalamas1 $\left(\overline{\boldsymbol{X}}_{\text {Öntest=46,20 }}\right)$ ile uygulama sonras1 yapılan puan ortalamas1 $\left(\overline{\boldsymbol{X}}_{\text {Sontest=65,96}}\right)$ arasında anlamlı bir fark görülmüştür $\left(\mathrm{t}_{49}:-12,145, \mathrm{p}<, 05\right)$. Bu anlamlı fark sayesinde verilen eğitimlerin okul öncesi öğretmen adaylarının yaratıcılık becerilerini geliştirdiği söylenebilir.

Araştırmanın nitel verileri ise araştırmanın amacına uygun olması ve nitel analiz yöntemlerinde sıkça karşılaşılan bir analiz yöntemi olması nedeniyle içerik analizi yapılmıştır. $\mathrm{Bu}$ analiz yöntemiyle elde edilen verilerin toparlanarak açıklanması için gereken olgulara, ilintilere, gizli gerçeklere ulaşmayı hedeflemektedir. Bu yöntemde araştırmacı tarafından sınırlandırılmış kodlar ortaya çıkarılarak ilgili kategoriler oluşturulmaktadır (Yıldırım ve Şimşek, 2008). Yapılan görüşme verileri bir kayıt altına 
alınarak veriler yazıya dönüştürülmüş ve içerik analizinin aşamalarına uygun olarak analiz edilmiştir. İçerik analizinde elde edilen nitel veriler içerik analizine uygun olarak verilerin kodlanması, kategorilerin bulunması, kodların ve kategorilerin düzenlenmesi-tanımlanması, bulguların yorumlanması olmak üzere toplamda dört aşamada analiz edilmiştir. Aşağıda her bir soru için ayrı ayrı içerik analizi yapılarak tablo oluşturulup yorumlanması yapılmıştır.

Tablo 2. "Bu etkinlikleri yaparken neler hissettiniz? Bu etkinliklerin nasll olmasinı isterdiniz?” sorusuna iliş̧kin ögretmen adayları görüşleri

\begin{tabular}{llrr}
\hline Kategori & \multicolumn{1}{c}{ Kod Adı } & f & \% \\
\hline & Dersin sayısı artırılmalı & 4 & 9,3 \\
& Devamı olmalı & 1 & 2,32 \\
Eğitime yönelik öneriler & Saatlik eğitim olmalı & 1 & 2,32 \\
& Bilim ilerlemeli & 1 & 2,32 \\
& Herkes bilinçlendirilsin & 1 & 2,32 \\
& Temel seviyeden itibaren verilmeli & 3 & 6,96 \\
\hline & Fene yönelik ön yargıları yıkma & 3 & 6,97 \\
& Çok eğlenceli ve güzel & 11 & 23,22 \\
Tutum & Heyecan verici & 2 & 4,64 \\
& İlgi çekici & 1 & 2,32 \\
& Hatalarda sinirlenme & 1 & 2,32 \\
& Yapamayınca oluşan kötü duygu & 1 & 2,32 \\
\hline & Derslerin dolu dolu geçmesi & 2 & 4,64 \\
& Akılda kalıcılık & 2 & 4,64 \\
Faydalar & Uygulamaya dönüklük & 2 & 4,64 \\
& Başarma hazzı & 1 & 2,32 \\
& Grupça olmanın özgüveni & 1 & 2,32 \\
& Ürün oluşturma zevki & 4 & 9,3 \\
& Farklı tasarımlar yapma & 1 & 2,32 \\
\hline Toplam & & 42 & $99,83(\%)$ \\
\hline
\end{tabular}

Tablo 2'de görüşme sonucu adayların soruya yönelik cevaplarına yer verilmiş ve 3 ayrı kategori ortaya çıkmıştır. Eğitime yönelik öneriler kategorisinde; dersin sayısı artırılmalı $(\mathrm{f}=4)$, devamı olmalı $(\mathrm{f}=1)$, saatlik eğitim olmalı $(f=1)$, temel seviyeden itibaren verilmeli $(f=3)$, bilim ilerlemeli $(f=1)$ ve herkes bilinçlendirilsin $(\mathrm{f}=1)$ kodları bulunmaktadır. Kategoride en fazla frekansa dersin sayısı artırılmalı $(\mathrm{f}=4)$ kodu sahiptir. Bu kodlarda öğretmen adayları aldıkları eğitime yönelik istek ve önerilerini belirtmişlerdir. Bunlar, etkinliklerin saatlik eğitimler halinde devamlı bir ders şekilde verilmesini, derslerin sayısının artırılmasını ve zorunlu ders olmasını, eğitimin en temel seviyeden itibaren verilmesi gerektiğini, liselerde hatta ortaokullarda bir eğitim olarak verilmeye başlanması gerektiğini, her yaş grubu öğrencinin bu eğitimle bilinçlendirilmesi ve bu sayede bilimin ilerlemesine katkı sağlanması gerektiğini ifade etmişlerdir. Tutum kategorisinde; fene yönelik ön yargıları yıkma ( $\mathrm{f}=3)$, çok eğlenceli ve güzel ( $\mathrm{f}=11)$, heyecan verici $(\mathrm{f}=2)$, ilgi çekici $(\mathrm{f}=1)$, hatalarda sinirlenme $(\mathrm{f}=1)$, yapamayınca oluşan kötü duygu $(\mathrm{f}=1)$ kodları bulunmaktadır. Bu kodlarda öğretmen adayları etkinlikleri yaparken yaşadıkları hislerini belirtmişlerdir. Kodlara bakıldığında en fazla frekansa sahip dersi çok eğlenceli bulduklarını belirten çok eğlenceli ve güzel ( $\mathrm{f}=11)$ kodudur. Öğretmen adayları etkinlikleri çok şaşırtıcı bulduklarını ve bunları yaparken çok eğlendiklerini, zevkli ve ilgi çekici bulduklarını, etkinliklerde sonuca ulaşamayınca sinirlenip, üzüldüklerini, yapılan bu etkinlikler sayesinde fen dersine yönelik ön yargılarının yıkıldığını, kendi ürünlerini ortaya çıkarmanın mutluluk verici ve müthiş bir duygu olduğunu belirtmişlerdir. Faydalar kategorisinde ise; derslerin dolu dolu geçmesi ( $\mathrm{f}=2$ ), akılda kalıcılık ( $\mathrm{f}=2$ ), uygulamaya dönüklük ( $\mathrm{f}=2$ ), başarma hazzı ( $\mathrm{f}=1)$, grupça olmanın özgüveni ( $\mathrm{f}=1)$, ürün oluşturma zevki $(\mathrm{f}=4)$, farklı tasarımlar yapma $(\mathrm{f}=1)$ kodları bulunmaktadır. Kategoride en fazla frekansa ürün oluşturma zevki $(\mathrm{f}=4)$ kodu sahiptir. $\mathrm{Bu}$ kodlarda öğretmen adayları etkinliklerin kendilerine sağladığı faydalardan bahsetmişlerdir. Yani derste uygulanan etkinliklerin teorikten çok uygulamaya dönük olması sebebiyle derste sıkılmadıklarını, bilgileri bizzat uygulamaya döktükleri için boşta kalmamış olması ve akılda 
kalıcılığının sağlandığını, farklı tasarım ve kendi ürünlerini oluşturmanın özgüvenlerini artırdığını, başarı duygusunu tattıklarını belirten ifadelere yer verilmiştir.

Tablo 3. "Bu etkinlikleri yapmaya başlamadan önce size verilen malzemelerle 'başka ne yapabilirim' diye düşündünüz mü? Neden?" sorusuna ilişkin öğretmen adayları görüşleri

\begin{tabular}{|c|c|c|c|}
\hline Kategori & Kod Adı & f & $\%$ \\
\hline \multirow{6}{*}{ Üretme } & Aynı malzemeden farklı ürünler & 1 & 4,76 \\
\hline & Günlük hayatta kullanılan ürünler & 1 & 4,76 \\
\hline & Farklı tasarımlar & 2 & 9,52 \\
\hline & Farklı fikirler & 1 & 4,76 \\
\hline & Artan bilgi artan yaratıcılık & 1 & 4,76 \\
\hline & Eksik malzeme tasarımı & 1 & 4,76 \\
\hline \multirow{5}{*}{ Beceri } & Eleştirel düşünme & 4 & 19,04 \\
\hline & Ufku açma & 1 & 4,76 \\
\hline & Yaratıc1lık & 2 & 9,52 \\
\hline & Bilgi sahibi olma & 1 & 4,76 \\
\hline & İşine odaklanma & 3 & 14,28 \\
\hline \multirow{3}{*}{ Duygu - Davranış } & Eksik malzeme giderme & 1 & 4,76 \\
\hline & Kazanma duygusu & 1 & 4,76 \\
\hline & Biran önce bitirme & 1 & 4,76 \\
\hline Toplam & & 21 & $100(\%)$ \\
\hline
\end{tabular}

Tablo 3'te görüşme sonucu adayların soruya yönelik cevaplarına yer verilmiş ve 3 ayrı kategori ortaya çıkmıştır. Üretme kategorisinde; aynı malzemeden farklı ürünler $(\mathrm{f}=1)$, günlük hayatta kullanılan ürünler $(\mathrm{f}=1)$, farklı tasarımlar $(\mathrm{f}=2)$, farklı fikirler $(\mathrm{f}=1)$, artan bilgi artan yaratıcılık $(\mathrm{f}=1)$, eksik malzeme tasarımı ( $\mathrm{f}=1)$ kodları bulunmaktadır. Kodlardan en fazla frekansa farklı tasarımlar $(\mathrm{f}=2)$ oluşturma kodu sahiptir. Bu kodlarda öğretmen adaylarının, etkinlikte verilen malzemelerden başka neler yapabilirdin sorusuna ilişkin farklı ürün ve tasarımlar yapabileceklerini, günlük yaşamda kullanılabilecek farklı tasarımlar, dekoratif eşyalar tasarlamak istediklerini ve etkinlik esnasında ihtiyaç duydukları malzemeleri tasarladıklarını belirten ifadelere yer verilmiştir. Ayrıca bu eğitimin birçok konuda bilgilerini artırdığını ve yaratıcılık becerilerini geliştirdiğini, farklı fikir ve yorumlar yürütebildiklerini belirtmişlerdir. Beceri kategorisinde; eleştirel düşünme ( $\mathrm{f}=4)$, ufku açma $(\mathrm{f}=1)$, yaratıcıllk $(\mathrm{f}=2)$, bilgi sahibi olma $(\mathrm{f}=1)$, işine odaklanma ( $\mathrm{f}=3$ ) kodları bulunmaktadır. Burada ise malzemeler ile farklı tasarımlar ve düşünceler geliştirme tutumu içerisine giren öğretmen adaylarının bu tutum sayesinde sınırlı düşüncelerden ufuk açıcı düşünmelere yöneldiklerini, eleştirel ve yaratıcı düşünme becerilerinin geliştiğini fark ettiklerini ve birçok fen konusunda bilgi sahibi olduklarını ifade etmişlerdir. Bazı öğretmen adayları ise verilen malzemelerle farklı tasarımlar oluşturmayı düşünmedikleri yalnızca belirlenen etkinliğe odaklandıklarını belirtmişlerdir. Duygu ve davranış kategorisinde ise; eksik malzeme giderme ( $\mathrm{f}=1)$, kazanma duygusu $(\mathrm{f}=1)$, bir an önce bitirme $(\mathrm{f}=1)$ kodları bulunmaktadır. Burada bireyler verilen etkinlik malzemelerinden eksikler olsa da hüsrana kapılmayıp eksik parçaları kendileri tasarlama davranışını öğrendiklerini, yarışma duygusuna kapılıp bir an önce bitirerek kazanma duygusunu tatmanın hazzına varmayı arzuladıklarını ifade etmişlerdir. 
Tablo 4. "Bu etkinlikler sizde farkl tasarımlar ortaya koyma isteğini oluşturdu mu?" sorusuna ilişkin ögretmen adayları görüşleri

\begin{tabular}{|c|c|c|c|}
\hline Kategori & Kod Adı & f & $\%$ \\
\hline \multirow{6}{*}{ İlgi } & Tasarımı sevme & 1 & 5,88 \\
\hline & Farklı tasarımlar oluşturma & 6 & 35,29 \\
\hline & Bir şeyler birleştirmeyi sevme & 1 & 5,88 \\
\hline & Ürün oluşturmayı sevme & 1 & 5,88 \\
\hline & Çok az farklı tasarım isteği & 2 & 11,76 \\
\hline & $\begin{array}{l}\text { Çocuklar için fen materyaller } \\
\text { yapma isteği }\end{array}$ & 1 & 5,88 \\
\hline \multirow{4}{*}{ Öğrenme } & $\begin{array}{l}\text { Sebep sonuç ilişkisi kurmayı } \\
\text { öğrenme }\end{array}$ & 1 & 5,88 \\
\hline & Aşamalı öğrenme & 1 & 5,88 \\
\hline & Yaratıcı olmayı öğrenme & 2 & 11,76 \\
\hline & $\begin{array}{lll}\text { Literatür } & \text { taraması } & \text { yapmay } \\
\text { öğrenme } & & \\
\end{array}$ & 1 & 5,88 \\
\hline Toplam & & 17 & $96,97(\%)$ \\
\hline
\end{tabular}

Tablo 4'te görüşme sonucu adayların soruya yönelik cevaplarına yer verilmiş ve 2 ayrı kategori ortaya çıkmıştır. İlgi kategorisinde; tasarımı sevme $(\mathrm{f}=1)$, farklı tasarımlar oluşturma $(\mathrm{f}=6)$, bir şeyler birleştirmeyi sevme ( $\mathrm{f}=1)$, ürün oluşturmayı sevme $(\mathrm{f}=1)$, çok az farklı tasarım isteği $(\mathrm{f}=2)$, çocuklar için fen materyaller yapma isteği $(\mathrm{f}=1)$ kodları bulunmaktadır. Kategori içerisinde en fazla kod farklı tasarımlar oluşturma $(\mathrm{f}=6)$ koduna aittir. Burada öğretmen adaylarının soruya verdikleri cevaplarda olumlu sonuçlar çıkmıştır. İki kişinin farklı tasarımlar oluşturma isteğinin çok az olduğu belirtilmiş, diğerleri ise farklı tasarım oluşturmaya ilgi ve isteklerinin arttığı görülmüştür. Bir şeyler oluşturmayı önceden de çok seven bazı adayların ise bu sevgisi iyice artmış olduğunu belirten ifadelere yer verilmiştir. Adaylardan bazıları etkinliklerden sonra özellikle çocuklar için fen materyalleri yapma isteklerinin arttığını belirtmişlerdir. Genel olarak etkinlikler öğretmen adaylarında farklı ürün ve tasarımlar ortaya çıkarma isteklerini ve bu alana ilgi duymaya başladıklarını ifade eden görüşlere yer verilmiştir. Öğrenme kategorisinde; sebep sonuç ilişkisi kurmayı öğrenme $(\mathrm{f}=1)$, aşamalı öğrenme $(\mathrm{f}=1)$, yaratıcı olmayı öğrenme $(\mathrm{f}=2)$, literatür taraması yapmayı öğrenme $(\mathrm{f}=1)$ kodları bulunmaktadır. $\mathrm{Bu}$ kodlarda adayların etkinliklerde ortaya koydukları tasarımlar sayesinde bazı yöntem ve becerileri öğrendiklerini içeren ifadelere yer verilmiştir. Kategori içerisinde en fazla frekans yaratıcı olmayı öğrenme $(\mathrm{f}=2)$ koduna aittir. Öğretmen adayları ortaya çıkan bir sorun karşısında sebep sonuç ilişkisi kurabilmeyi, o konu hakkında önceki yapılmış çalışmalara bakıp araştırma-inceleme yapabilmeyi, yaratıcı düşünebilmeyi ve sonuca aşama aşama yaparak ulaşılabileceğini öğrendiklerini belirten ifadelere yer verilmiştir. 
Tablo 5. "Kendi düzeneğinizi, tasarımınızı yapmak nasıl bir duyguydu? Açıklar mısınız?" sorusuna ilişkin ögretmen adayları görüşleri

\begin{tabular}{llrr}
\hline Kategori & \multicolumn{1}{c}{ Kod Adı } & f & \% \\
\hline \multirow{2}{*}{ Tasarım } & Yeni ürünler oluşturma & 1 & 4 \\
& Kendi ürününü yapma & 3 & 12 \\
\hline & Heyecanlı & 1 & 4 \\
& Sevinçli & 1 & 4 \\
& Başarma duygusu & 1 & 4 \\
& Güzel & 4 & 16 \\
& Yapabilme inancı & 1 & 4 \\
Duygu - Düşünce & Özgüven artırıcı & 3 & 12 \\
& Muhteşem & 1 & 4 \\
& Hüsrana uğramama & 4 & 16 \\
& Yaratıcı hissetme & 3 & 12 \\
& Harika & 1 & 4 \\
& Zevkli & 1 & 4 \\
\hline Toplam & & 25 & $100(\%)$ \\
\hline
\end{tabular}

Tablo 5'te görüşme sonucu adayların soruya yönelik cevaplarına yer verilmiş ve 2 ayrı kategori ortaya çıkmıştır. Tasarım kategorisinde; yeni ürünler oluşturma ( $\mathrm{f}=1)$, kendi ürününü yapma $(\mathrm{f}=3)$ kodları bulunmaktadır. Kategoride en fazla frekans kendi ürününü yapma $(\mathrm{f}=3)$ koduna aittir. Öğretmen adayları burada etkinliklerde kendi ürünlerini tasarlayabilmenin onlar1 yeni ürünler oluşturma isteğine yönlendirdiğini ifade etmiştir. Duygu - düşünce kategorisinde; heyecanlı ( $\mathrm{f}=1)$, sevinçli $(\mathrm{f}=1)$, başarma duygusu ( $\mathrm{f}=1$ ), güzel $(\mathrm{f}=4)$, yapabilme inanc1 $(\mathrm{f}=1)$, özgüven artırıcı $(\mathrm{f}=3)$, muhteşem $(\mathrm{f}=1)$, hüsrana uğramama ( $\mathrm{f}=4)$, yaratıcı hissetme ( $\mathrm{f}=3)$, harika $(\mathrm{f}=1)$, zevkli $(\mathrm{f}=1)$ kodları bulunmaktadır. Kategoride en fazla frekans güzel $(\mathrm{f}=4)$ ve hüsrana uğramama $(\mathrm{f}=4)$ kodları sahiptir. Bu kodlarda öğretmen adayları kendi tasarımlarını yapmanın verdiği duygu ve düşüncelere yer verilmiştir. Adaylar etkinlikleri yaparken mutlu hissettiklerini, zevk aldıklarını, kendilerini yaratıcı hissettiklerini, bir ürün ortaya koymanın yaratıcılıklarını ve özgüvenlerini artırdıklarını, başarma duygusunu tattıklarını, sorunlar karşısında yapabilme inançlarının arttığını belirten ifadelere yer verilmiştir.

Tablo 6. "Zor bir durumla karşılaştığınızda var olan bilginizi ya da yeni bilgilerinizi kullanmak ister misiniz?” sorusuna ilişkin öğretmen adayları görüşleri

\begin{tabular}{llrr}
\hline Kategori & \multicolumn{1}{c}{ Kod Adı } & f & \multicolumn{1}{c}{$\%$} \\
\hline \multirow{3}{*}{ Bilgi Kullanım } & Yeniliğe açık olma & 1 & 7,69 \\
& Bilgi birikimi- deneyim & 1 & 7,69 \\
& Mevcut bilgi & 7 & 53,84 \\
& Yeni bilgi arayışı & 4 & 30,76 \\
\hline Toplam & & 13 & $99.98(\%)$ \\
\hline
\end{tabular}

Tablo 6'da görüşme sonucu adayların soruya yönelik cevaplarına yer verilmiş ve tek kategori ortaya çıkmıştır. Bilgi kullanım kategorisinde; yeniliğe açık olma ( $\mathrm{f}=1)$, bilgi birikimi- deneyim ( $\mathrm{f}=1)$, mevcut bilgi $(\mathrm{f}=7)$, yeni bilgi arayışı $(\mathrm{f}=4)$ kodları bulunmaktadır. Kategoride en fazla frekans mevcut bilgi $(\mathrm{f}=7)$ koduna aittir. Öğretmen adayları bu kodlarda soruya cevap olarak yeniliğe açık olduklarını ve yeni bilgiler öğrenip kullanmak istediklerini, etkinliklerde yaşadıkları deneyimlerle sahip oldukları bilgi birikimlerini kullanabileceklerini ve eğer yetersiz gelirse de yeni bilgi arayışlarına girebileceklerini, bazı adaylar da zor durumlar karşısında öncelikli olarak mevcut bilgilerini kullandıklarını belirten ifadelere yer verilmiştir. 
Tablo 7. "Bu etkinliklerde size verilen malzemeleri değiştirme imkânınız olsa neleri değişstirip, neler yapmak isterdiniz?” sorusuna ilişkin ögretmen adayları görüşleri

\begin{tabular}{llcc}
\hline Kategori & \multicolumn{1}{c}{ Kod Adı } & f & \% \\
\hline \multirow{4}{*}{ Tasarım } & Gazlı balonla uçan araba & 1 & 7,14 \\
& Gerçek camı olan araba sileceği & 2 & 14,28 \\
& Bütün materyalleri birleştirip proje & 1 & 7,14 \\
& çkarma & & \\
& Küçük tekerlekli balonlu araba & 1 & 7,14 \\
\hline & Daha çok etkinlik yapma & 1 & 7,14 \\
& Yapılan materyali bozmama & 1 & 7,14 \\
Yapmak İstenilen & Malzemeleri kendisi bulma & 1 & 7,14 \\
& Daha ucuza mal etme & 1 & 7,14 \\
& Hazır verileni yapma & 1 & 7,14 \\
& Gruplar arası malzeme değişimi & 4 & 28,57 \\
\hline Toplam & & 14 & $99.97(\%)$ \\
\hline
\end{tabular}

Tablo 7'de görüşme sonucu adayların soruya yönelik cevaplarına yer verilmiş ve 2 ayrı kategori ortaya çıkmıştır. Bu kategoriler sırasıyla tasarım kategorisi; gazlı balonla uçan araba $(\mathrm{f}=1)$, gerçek camı olan araba sileceği $(\mathrm{f}=2)$, bütün materyalleri birleştirip proje çıarma $(\mathrm{f}=1)$, küçük tekerlekli balonlu araba $(\mathrm{f}=1)$ kodları bulunmaktadır. Kategoride en fazla frekans gerçek camı olan araba sileceği $(\mathrm{f}=2)$ koduna aittir. Burada öğretmen adayları yapılan etkinliklerdeki malzemelerden kendilerine göre neyi değiştirip ne yapmak istediklerini belirtmişlerdir. Bazıları balonlu araba etkinliğinde normal balon değil helyum gazıyla dolu olan bir balon kullanarak yerde giden araba değil uçan bir araba yapmak istediklerini, bazıları daha küçük tekerleklere sahip arabalar yapmak istediklerini, bazıları robotik kodlama legolarında araba sileceği etkinliğinde gerçek cama sahip ve su fişkırtan bir malzeme kullanarak bir araba sileceği yapmak istediklerini ve bazıları da yapılan bütün bu etkinliklerin bozulmadan saklayarak dönem sonunda bunlardan büyük bir proje yapmak istediklerini belirten ifadelere yer verilmiştir. Yapmak istenilen kategorisinde ise; daha çok etkinlik yapma $(\mathrm{f}=1)$, yapılan materyali bozmama $(\mathrm{f}=1)$, malzemeleri kendisi bulma ( $\mathrm{f}=1)$, daha ucuza mal etme ( $\mathrm{f}=1)$, hazır verileni yapma $(\mathrm{f}=1)$, gruplar arası malzeme değişimi $(\mathrm{f}=4)$ kodları bulunmaktadır. Kategoride en fazla frekans gruplar arası malzeme değişimi $(\mathrm{f}=4)$ koduna aittir. Öğretmen adayları malzemeler ve etkinlikler hakkındaki isteklerini; etkinlik malzemelerini kendileri bularak (temin etmesini) daha ucuza mal edebileceklerini, etkinliklerin daha da çok olmasını ve bunun sonraki dönemlerde de devam etmesini istediklerini, gruplar arasında malzeme değiş tokuşları yapmak istediklerini ve bazıları ise herhangi bir değişiklik yapmak istemediklerini ve verilen hazır malzemeleri kullanarak etkinliklerini tamamlamak istediklerini belirten ifadelere yer verilmiştir.

\section{SONUÇ ve TARTIŞMA}

Montessori yaklaşımı temelli STEM etkinliklerinin okul öncesi öğretmen adaylarındaki yaratıcılık becerilerine olan etkisini ölçmek amacıyla yapılan nicel analiz sonuçlarında ön test ve son test puanları arasında anlamlı fark saptanmıştır. Araştırmadan elde edilen bulgular doğrultusunda Montessori yaklaşımı temelli STEM etkinliklerinin okul öncesi öğretmen adaylarının yaratıcılık becerilerini geliştiği yönünde yorum yapılabilir. Çalışma sonuçlarını destekler nitelikte Adıgüzel vd. (2012), Kaya (2010), Kökdemir (2003) ve Uğraş (2017); çalışmalarında STEM eğitiminin; disiplinler arası bir bakış açısı kazandıracağı, problem çözebilme, mühendislik tasarımları, bilimsel süreç, analitik düşünebilme, yaratıcılıklarını ve 21. yy becerilerini geliştirdiğini içeren düşünce ve sonuçlara yer vermiş̧lerdir. SungurGül ve Marulcu (2014) çalışmalarında öğretmen ve ögretmen adaylarının mühendis, mühendislik algıları, yöntem olarak mühendislik-dizayn ve ders materyali olarak legolara bakış açılarını incelemişlerdir. Sonuç olarak mühendislik ve mühendisler hakkında seminerden önce ortalama düzeyde bilgi sahibi olduklarını ve böyle bir eğitimin sonunda da öğretmenlerin algılarında olumlu yönde belirgin bir değişiklik gösterdiğini belirtmişlerdir. Ayrıca öğretmenlerin, mühendislik-dizayn temelli bir dersin öğrencilerin yaygın olarak psikomotor, yaratıcı ve sosyal düşünme becerilerini geliştireceğini belirten ifadelerine yer vermişlerdir. Elkin, et al. (2014), erken çocukluk dönemi Montessori sınıflarında robotik müfredatının uygulanması isimli çalışmalarında, Montessori yaklaşımının robotik eğitimleri ile birlikte 
entegre edilmesinin, çocuklar için yeni fikirler üretebilme ve yaratıc1lığ geliştireceğine yönelik önemi vurgulanmıştır. Altun Yalçın ve Yalçın (2018), fen bilgisi öğretmen adaylarının yapılan uygulama süreci sonunda STEM eğitimi konusundaki metaforik algılarının incelenmesi isimli çalışmalarında, adayların STEM eğitimine yönelik belirttikleri metaforlarda özellikle yaratıcılığa vurgu yapan ifadeleri "tasarım, sistem, yeni șeyler üretme, kurgu, zekâ, yapboz, mühendislik, basit makine" kullandıklarını belirtmişlerdir. Strong (2013); araştırmasında STEM eğitiminin bilimsel süreç becerilerini (yaratıcılık, eleştirel düşünme, problem çözme) geliştirdiğini, Sullivan (2008)' da; bunlara ek olarak robotik ve bilim okuryazarlığı eğitimlerinin öğrencinin düşünme ve bilimsel süreç becerilerinin olumlu yönde geliştirdiğine katkı sağladığını belirtmişlerdir.

Çalışmanın yaratıcılık becerilerine yönelik yapılmış olan nitel sonuçları da nicel sonuçlarını desteklemektedir. Adaylar etkinliklerin ilk haftalarından sonra etkinliklerde ne yapılacağı, tam olarak ne istendiği gibi belli başlı konular yerine artık etkinliklerde her grup kendine has bir tasarımla (sanatsal, ürünün uygulanabilirliği, daha az maliyet tarzı açılardan), zihinlerinde daha güzel neler tasarlayabilirim sorularıyla, yaratıcılıklarını ortaya çıkararak bir ürün oluşturduklarını, etkinlik sırasında eksik çıkan malzemenin giderilmesi için kendi yaratıcılıklarını kullanarak ellerinde bulunan farklı malzemeleri birleştirerek gerekli olan malzemeyi oluşturabildiklerini, bazı etkinlikler sonunda yapılan grup yarışmalarında kazanma duygusunun bireyleri zamanı etkili ve verimli kullanarak en dayanıklı, amaca en uygun ve en hızlı olabilecek şekilde ürünlerini tasarlamak için grupça yaratıcı becerilerini ortaya koyduklarını belirtmişlerdir. STEM eğitimlerinin bireyin yaratıcılık becerilerini geliştirdiği sonuçları destekler nitelikte Knezek et al. (2013) çalışmalarında, uygulamalı projelerin öğrencilerin STEM içerik bilgisi ve hakkındaki görüşleri üzerindeki etkisini incelemişlerdir. Sonuç olarak öğrencilerin uygulama sonrasında STEM içerik bilgilerini kazandıkları ayrıca STEM konuları ve meslekleri ile ilgili olarak yaratıcı eğilimlerinin ve algılarının geliştiğini ifade etmişlerdir.

Çalışmanın nitel sonuçları arasında yine öğretmen adayları etkinliklerde sonuca ulaşamadıklarında veya etkinlikler sonrasında karşılaştıkları herhangi bir probleme yönelik olarak farklı çözüm yolları bulmaya çalıştıklarını, sonuca ulaşmada pes etmemeyi ve sonuna kadar fikir üreterek, ürettiğini deneyip eksiklerini görerek bir sonraki uygulamasında üstüne öğrendiklerini katıp ilerlemeyi, zor bir durum karşısında yeni bilgi arayışına girmeyi öğrendiklerini belirtmişlerdir. Çalışma sonuçlarındaki STEM' e yönelik olumlu tutumları destekler nitelikte Gülhan ve Şahin (2016); STEM eğitiminin öğrencilerin tutumları üzerine etkisini incelemiş ve uygulama sonucunda STEM eğitiminin öğrencilerin tutumlarını olumlu yönde geliştirdiğini belirtmişlerdir. Seong-Hwan (2013) çalışmalarında STEM uygulamalarının ögrencilerin STEM disiplinlerine karşı tutumlarına olumlu yönde etkisi olduğunu belirtmiştir. Öğretmen adaylarından bazıları etkinlikler sonrasında kendi tasarımlarını oluşturarak daha farklı ürünler ortaya koymak istediklerini belirtmişlerdir. Adayların kendi hayallerindeki tasarımlar ve değiştirmek istedikleri malzemeler; gazla uçan bir araba yapmak istediğini, robotik kodlama legolarında gerçek cam kullanarak su sıkan tam bir araba sileceği yapmak istediklerini, yapılan bütün etkinlikleri dönem sonunda bir araya getirerek bir proje yapmak istediklerini, daha küçük tekerlekler kullanılarak bir balonlu araba etkinliğini yapmak gibi isteklerini belirtmişlerdir. Adaylar bu etkinlikler ile bir problemin çözümüne yönelik sebep sonuç ilişkisi kurarak yaratıcı olmayı, yaptığı etkinliklerde karşılaştığı problemler nedeniyle artık bu tarz problemlerde önceden önlemini alabilmeyi, fen öğretimini kolaylaştırdığını ve fen konularının zevkli yanlarını görerek çocuklara fen alanında farklı bilimsel bakış açıları kazandırabileceklerini öğrendiklerini ifade etmişlerdir. Tezel ve Yaman (2017)' nın STEM eğitimine yönelik gerçekleştirdikleri derleme çalışmalarındaki STEM eğitimi hakkındaki vurguları sonuçları desteklemektedir. Bunlar STEM eğitiminin fen, teknoloji, matematik ve mühendislik alanlarına ait bilgi ve becerilerin mühendislik tasarımı odaklı bir öğretim üzerinde bütünleştirilmesine odaklanan, öğrencilere disiplinler arası işbirliği, sistematik düşünebilme, yaratıcılık ve problem çözebilme becerilerini kazandıran bir eğitim olduğunu vurgulamışlardır. Yine çalışmanın yaratıcılığı, öğrenme isteğini ve düzeyini artırdığını destekler nitelikte olan Cho ve Lee (2013) çalışmalarında, STEM eğitimi etkinliklerini temel alarak hazırlanan ders planlarının öğrencilerin yaratıcılık, problem çözme ve öğrenme düzeylerine yönelik etkisini araştırmışlardır. Sonuç olarak öğrencilerin yaratıcılıklarının ve öğrenme düzeylerinin geliştiğine ulaşmışlardır. Çalışmanın fen öğretimini kolaylaştırdığını ifade eden nitel sonuçlarını destekler nitelikte olan Fortus et al. (2004) çalışmalarında, STEM eğitiminin lise öğrencilerinin öğrenme düzeyleri üzerindeki etkisini araştırmışlardır. Sonuç olarak tasarımların fen öğretiminde köprü oluşturduğunu, 
bilimsel bilginin yapılandırılmasında uygulanan tasarımların etkili olduğunu belirtmişlerdir. Venville et al. (2000) çalışmalarında, fen, matematik ve teknolojide bütünleştirici eğitimin geleneksel disiplin temelli eğitim ortamlarında uygulandığında sonuçlarının ne şekilde değişim göstereceğini ve bütünleştirici eğitimin öğrencilerin öğrenmelerine olan etkisini incelemişlerdir. Sonuç olarak öğrencilerin öğrenmeye olan ilgilerinin artmış olduğu ve STEM derslerindeki bütünleştirici yaklaşımların normal eğitim ortamlarından ziyade yapılandırmacı eğitim ortamlarında uygulanması gerektiğini ifade etmişlerdir. Siew et al. (2015) çalışmalarında, öğretmen adayları ve öğretmenlerin fen derslerinde STEM ögretimi yaklaşımının kullanımı ile ilgili olumlu düşünceye sahip olduklarını belirtmişlerdir. Yıldırım ve Selvi (2017) STEM uygulamaları ve tam öğrenmenin ortaokul öğrencilerinin öğrenme üzerine etkilerini incelemiş ve sonucunda STEM uygulamaları ve tam öğrenmenin öğrencilerin akademik başarı ve fene yönelik motivasyonları üzerine olumlu etki yaptığını bulmuşlardır. Riskowski (2009) çalışmasında, 8. sınıfta öğrenim gören ve herhangi bir mühendislik proje deneyimine sahip olmayan öğrencilere, su kaynaklarıyla ilgili bir mühendislik projesi uygulanmıştır. Bu araştırmada, fen eğitimi konusunda bütünleştirici STEM eğitimiyle ilgili olarak yapılan proje yönteminin fen bilgisi öğrenimi üzerinde olumlu etkileri olduğu gözlenmiştir. Gökbayrak ve Karışan (2016) STEM uygulamalarına yönelik çalışmalarında, STEM' in öğrencilerin ilgi ve motivasyonlarını arttırdığı sonucuna ulaşmıştır. Bakırcı ve Kutlu (2018) Fen bilimleri öğretmenlerinin STEM eğitimi hakkındaki görüşlerini incelemişlerdir. Sonuç olarak öğretmenler, STEM eğitiminin öğrencilerin derse karşı ilgi ve motivasyonlarının artıracağını, farklı bakış açıları kazanacaklarını ve karar verme becerilerini geliştireceğini belirtmişlerdir. Ayrıca STEM eğitimiyle öğrencilerin bilgiyi yaparak yaşayarak öğreneceklerini, yaratıcı ve araştırmasorgulama becerilerini geliştireceklerini, problem durumuna uygun ürünler tasarlayacaklarını, konuları somutlaştırarak kalıcı öğrenmeler sağlanacağını ve bilimsel süreç becerilerinin gelişeceğini belirtmişlerdir. Montessori yaklaşımı temelli STEM etkinliklerinin bireyin bilimsel süreç becerilerini geliştirdiğine yönelik çıkan sonuçları destekleyen bir çalışma olarak, Şahintürk (2012) çalışmasında öğrencilerin yaratıcı düşünme becerilerinde Milli Eğitim programının ve Montessori yaklaşımının etkisini incelemiştir. Sonuç olarak Montessori yaklaşımının normal eğitime göre çocukların yaratıcılık becerilerini daha çok geliştirdiğini belirtmiştir. Yine Siew et al. (2015), yaptıkları çalışmada STEM ile ilgili olarak yaratıcılık ve düşünme becerileri açısından model tasarlamanın fen derslerinde öğretmen ve öğretmen adaylarında gelişim sağladığını hatta bilimsel süreç becerilerine katkı sağladığı ifade edilmiştir. Karlıdağ (2018), okul öncesi öğretmenlerinin yaratıcılık kavramına ilişkin görüşlerini araştırmıştır. Araştırmada nitel analizler yapılmıştır. Yapılan analiz sonuçlarında yaratıcıllı̆ın özgün bir ürün ortaya çıkarma süreci olarak görüldüğü ve oldukça önemli bir kavram olduğu belirtilmiştir. Öğrenim merkezlerinin çeşitli materyallerle düzenlenmesinin, yeni ortamların oluşturulmasının yaratıcılığı desteklediğini belirtmiştir. Bu ifadeler çalışmanın nitel sonuçlarını destekler niteliktedir. Okul öncesi öğretmen adaylarının öğrendikleri etkinlikleri kendi bölümlerindeki sunumlarına ekleyerek feni daha çok kullanmaya başladıklarını, ileride meslek hayatlarında derslerinde bu tarz etkinlikleri kesinlikle kullanacaklarını, bu eğitimin temelden verilmesi gerektiğini belirtmişlerdir. Ayrıca basit malzemeler ile olan etkinlikleri diğer etkinliklere (robotik kodlama ve web 2 araçları) göre malzemelerinin karşılanması zor olacağı için daha çok yaptıracaklarını belirtmişlerdir. Knezek et al. (2013) çalışmalarında, uygulamalı projelerin ortaokul öğrencilerinin STEM bilgi ve görüşleri üzerindeki etkilerini araştırmışlardır. Çalışmanın bulgularında, öğrencilerin uygulamadan sonra STEM konuları ve STEM meslekleri hakkında yaratıcı eğilimlerinin, STEM'e yönelik tutumlarının geliştirdiğini ve STEM içerik bilgilerini kazandıklarını ortaya koymuşlardır. Aynı zamanda öğretmenler STEM eğitimlerinin okul öncesi dönemden itibaren verilmesi gerektiğini belirtmişler ancak okullarda konuyla ilgili eğitim ve gerekli malzemelerin eksikliğinden kaynaklı olarak uygulanmasının zor olacağını belirtmişlerdir. Yine literatürde STEM eğitiminin okul öncesi dönemden itibaren uygulanması gerektiğini belirten benzer çalışmalar bulunmaktadır (Katz, 2010; Yıldırım ve Selvi, 2016; Soylu, 2016). Ayrıca Çepni (2017) Amerika' da ilköğretimden itibaren yapılan STEM uygulamalarında öğrenciler üzerinde olumlu etkiler bıraktığını fakat ilerde meslek seçimlerinde STEM alanlarını tercih etmediklerini belirtmişlerdir. $\mathrm{Bu}$ durumda STEM eğitiminin temel seviye olan okul öncesi dönemden itibaren verilmesi gerekliliğini ortaya çıkardığını belirtmişlerdir. Uyanık Balat ve Günşen (2017) okul öncesi dönemde kavram oluşumu, kazanımı ve kullanımı daha aktif olması sebebiyle çocukların fizik, kimya, biyoloji ve matematik gibi temel bilimlerin ortaya koyduğu kuramsal bilgileri alarak teknoloji ve mühendisliği harmanlayıp gelecekte yaşama değer katacak yenilikler yapabilmesinin mümkün olduğunu ifade 
etmişlerdir. Dolayısıyla STEM yaklaşımının erken çocukluk yılları itibariyle uygulanması gerekliliğini önermektedirler. Uğraş (2017) okul öncesi öğretmenlerinin STEM' e yönelik görüşlerini incelemiş ve sonucunda bu eğitimin okul öncesi dönemden itibaren verilmesini içeren öğretmen görüşlerine yer vermişlerdir. STEM alanına yönelik ilginin artması sonucunu destekler nitelikte olan Pekbay (2017) çalışmasında, STEM etkinliklerinin ortaokul öğrencilerinin günlük yaşama dayalı problem çözme becerilerine ve STEM alanlarına yönelik ilgilerini araştırmıştır. Sonuç olarak öğrencilerin günlük yaşama dayalı problem çözme becerilerini geliştirdiği ve STEM alanına yönelik ilgilerinde olumlu yönde bir gelişim olduğunu belirtmiştir. Judson (2014) çalışmasında, STEM uygulamalarının öğrencilerin akademik başarıları üzerine yaptığı deney ve kontrol gruplu araştırma sonucunda STEM uygulanan deney grubu ile uygulanmayan kontrol grubu arasında akademik başarı açısından anlamlı bir farklılık bulduğu gözlenmiş̧ir. Yine Cosentin, (2008), Green, (2012), Hill (2002), Kang, Ju ve Jang (2013); çalışmalarında benzer STEM uygulamalarının akademik başarıyı artırdığına yönelik sonuçlara yer vermişlerdir.

\section{5. ÇALIŞMANIN SINIRLILIKLARI ve ÖNERİLER}

Montessori yaklaşımı temeli esas alınarak hazırlanan STEM etkinlikleri uygulamalarının öğretmen adaylarının yaratıcılık becerileri ve görüşleri üzerine etkisinin incelendiği bu çalışmanın sınırlılıkları ve bu sınırlılıklar neticesinde yapılacak çalışmalar için yapılan öneriler bulunmaktadır. Bu çalışma bir devlet üniversitesinin eğitim fakültesi okul öncesi öğretmenliği 3. sınıfına devam eden öğretmen adayları ile gerçekleştirilmiştir. Bu çalışma doğrultusunda yapılacak olan başka yeni çalışmalar farklı fakülte ve sınıflar üzerinde (son sınıflardaki öğretmen adaylarının kpss üzerine yoğunluk verdikleri için etkinliklere yeterince odaklanamamaları nedeniyle 4. Sınıf öğrencileri hariç) gerçekleştirilebilir. Montessori yaklaşımı temelli STEM uygulamalarını öğrenen okul öncesi öğretmen adayları ile birlikte farklı okul öncesi okullarına gidilerek uygulamalar yapılıp etkilerine bakılabilir. Ayrıca farklı okullardaki okul öncesi öğretmenleri ile belli bir dönem eğitimlerini aldıktan sonra birlikte okul öncesi okullarında uygulamalar yapılabilir. Bu çalışma toplamda 14 hafta boyunca gerçekleştirilmiştir. Bu çalışma daha uzun süreçlerde çalışabilir ve çalışma sonucunda elde edilen ürünler bir proje kapsamında bir araya getirilerek sunulabilir. Ayrıca çalışmanın bir üniversitede gerçekleşmesi ve okul öncesi fen eğitimi dersi kapsamında belirli bir sürede tamamlanması da çalışmanın etkilerinin tartışılmasında sınırlama oluşturmaktadır. Araştırmacılar tarafından geliştirilen Montessori yaklaşımı temelli STEM uygulamalarının okul öncesi fen eğitimi dersi kapsamında sınırlı bir şekilde ele almak yerine tek başına bir ders olarak öğretmen adaylarının yetiştirilmesi önerilebilir. Ayrıca yeni eğitim programlarından biri olan STEM Eğitimi konusunda okul öncesi dönemdeki Montessori yaklaşımı temel alınarak okul öncesi öğretmenlerin yetiştirilmesi, bu eğitim programını milli eğitimin müfredatına uygun bir biçimde derslerinde uygulayabilen ve bu konuda yetkin birer eğitimci haline gelmelerini sağlamaktır. Böylece öğretmenlerin ders içeriklerini STEM ile zenginleştirerek öğrencilerin daha verimli dersler geçirmesi ve daha fazla öğrenim gerçekleştirmelerini sağlayarak geleceğin kaliteli bireylerinin yetiştirilmesine katkı sağlamaktır. Çalışmada; Okul Öncesi Öğretmen Adaylarından oluşan toplamda 50 öğretmen adayına Montessori yaklaşımı temelli STEM etkinliklerini teorik bilgi ve uygulamaya dönük beceri kazanmaları için gerekli uygulamalar yaptırılmıştır.

\section{KAYNAKÇA}

Adıgüzel, T., Ayar, M. C., Corlu, M. S., ve Özel, S. (2012). Fen, teknoloji, mühendislik ve matematik eğitimi: disiplinler arası çalışmalar ve etkileşimler. 10. Ulusal Fen Bilimleri ve Matematik Ĕ̈itimi, Niğde.

Akgündüz, D. ve Akpınar, B. C. (2018). Okul öncesi eğitiminde fen eğitimi temelinde gerçekleştirilen STEM uygulamalarının öğrenci, öğretmen ve veli açısından değerlendirilmesi. Yaşadıkça Eğitim, 32(1), 1-26.

Aksoy, B. (2004). Coğrafya öğretiminde probleme dayalı ögrenme yaklaşımı. Yayımlanmamış doktora tezi, Gazi Üniversitesi Eğitim Bilimleri Enstitüsü, Ankara. 
Allen, A. (2016). Don't fear STEM you aready teach it. School Age/After School Exchange, September/October, 56-59.

Altun Yalçın, S. ve Yalçın, P. (2018). Fen bilgisi öğretmen adaylarının STEM eğitimi konusundaki metaforik algilarının incelenmesi. International Journal of Social Science, 70, 39-59.

Aslan-Tutak, F., Akaygün, S. ve Tezsezen, S. (2017). İşbirlikli FeTeMM (fen, teknoloji, mühendislik, matematik) eğitimi uygulaması: kimya ve matematik öğretmen adaylarının FETEMM farkındalıklarının incelenmesi. Hacettepe Üniversitesi Eğitim Fakültesi Dergisi, 32(4), 794816.

Bakırc1, H. ve Kutlu, E. (2018). Fen Bilimleri Öğretmenlerinin Fetemm Yaklaşımı Hakkındaki Görüşlerinin Belirlenmesi. Türk Bilgisayar ve Matematik Eğitimi Dergisi, 9(2), 367-389.

Büyüköztürk, Ş., Kılıç- Çakmak, E., Akgün, Ö. E., Karadeniz, Ş. ve Demirel, F. (2016). Bilimsel Araştırma Yöntemleri. 21. Baskı. Ankara: Pegem Yayıncılık.

Breiner, J. M., Harkness, S. S., Johnson, C. C. and Koehler, C. M. (2012). What is STEM? a discussion about STEM about conceptions of STEM in education and patnerships. School Science and Mathematics, 112, 3-11.

Bybee, R. W. (2010). Advancing STEM education: A 2020 Vision. Technology and Engineering Teacher, 70(1), 30-35.

Can, A. (2016). SPSS ile bilimsel araştırma sürecinde nicel veri analizi. 6. Bask1. Ankara: Pegem Akademi.

Çepni, S. (2017). Kuramdan uygulamaya STEM+A+E eğitimi. 1. Bask1. Ankara: Pegem Akademi.

Cho, B. and Lee, J. (2013). The effects of creativity and flow on learning through the STEAM education on elementary scholl contexts. Paper presented et the International Conference of Educational Technology, Sejong University, Sout Korea.

Cosentino, C., (2008). The impact of integrated programming on student attitude and achievement in grade 9 academic mathematics and science. Unpublished Master's Thesis. Brock University, Ontario.

Çolakoğlu, M. ve Günay Gökben, A. (2017). Türkiye'de eğitim fakültelerinde FeTeMM (STEM) çalışmaları. İnformal Ortamlarda Araştırmalar Dergisi, 2(2), 46-69.

Çorlu, S. ve Çorlu, M. A. (2012). Scientific inquiry based professional development models in teacher education. Educational Sciences: Theory \& Practice, 12(1), 514-52.

Çorlu, M. S. (2014). FeTeMM eğitimi makale çağrı mektubu. Turkish Journal of Education, 3(1), 4-10.

Creswell, J. W. and Tashakkori, A. (2007). Differing perspectiveson mixed methods research. Journal of Mixed Methods Research, 1(4), 303-308.

Creswell, J. W. (2002). Educational research: Planning, conducting, and evaluating quantitative and qualitative research. Columbus, Ohio: Upper Saddle River, NJ.

Dereli, E. (2017). Montessori eğitim programının çocukların psikososyal gelişimlerine ve sosyal problem çözme becerilerine etkisinin incelenmesi. Ahi Evran Üniversitesi Kırşehir Eğitim Fakültesi Dergisi (KEFAD), 18(2), 135-153. 
Diamond, A. and Lee, K. (2011). Interventions shown to aid executive function development in children 4-12 years old. Science Journal, 333(6045), 959-964.

Durakoğlu, A. (2011). Maria Montessori’ye göre okul öncesi çocukluk döneminin özellikleri. Dicle Üniversitesi Ziya Gökalp Eğitim Fakültesi Dergisi, 16, 133-145.

Elkin, M., Sullivan, A. and Bers, M. U. (2014). Implementing a robotics curriculum in an early childhood Montessori Classroom. Journal of Information Technology Education, Innovations in Practice, 13, 153-169.

Eratay, E. (2009). Montessori Yönteminin Etkililiği. 19. Ulusal Özel Eğitim Kongresi, 22-24 Ekim Marmaris.

Fortus, D., Dershimer, R. C., Krajcik, J. S., Marx, R. W. and Mamlok-Naaman, R. (2004). Desing-Based Science and Student Leasrning. Journol of Research in Science Teaching, 41(10), 1081-1110.

Gökbayrak, S. ve Karışan, D. (2017). Altıncı sınıf öğrencilerinin FeTeMM temelli etkinlikler hakkındaki görüşlerinin incelenmesi. Alan Eğitim Araşstırmaları Dergisi, 3(1), 25-40.

Gülhan F. ve Şahin, F (2016). The effects of science-technology-engineering-math (STEM) integration on 5th grade students' perceptions and attitudes towards these areas. Journal of Human Sciences, 13(1), 602-620.

Green, A., (2012). The integration of engineering design projects into the secondary science classroom. Unpublished Master's Thesis, Michigan State University, Michigan.

Hadzigeorgiou, Y. (2002). Okul öncesi çocuklarda mekanik stabilite kavramının gelişimi üzerine bir çalışma. Fen Ĕgitimi Araştırmaları, 32(3), 373-391.

Hill, M.D., (2002). The effects of integrated mathematics/science curriculum and instruction on mathematics achievement and student attitudes in grade six. Unpublished doctoral dissertation. Texas A\&M University, Texas.

İşmen, E. (2001). Duygusal zeka ve problem çözme. M. Ü. Atatürk Eğitim Fakültesi Eğitim Bilimleri Dergisi, 13, 111-124.

Judson, E., (2014). Effect of Transferring to STEM focused charter and magnet schools on student achievement. The Journal of Educational Research, 107, 255-266.

Kang, J., Ju, E.J. ve Jang, S., (2013). The Effect of Science-based STEAM program using a portfolio on elementary students' formation of science concepts. Elementary Science Education, 32(4), 593-606.

Karlıdağ, İ. (2018). Okul Öncesi Öğretmenlerinin Yaratıcılık Kavramına İlişkin Görüşleri. Journal of International Social Research, 11(56), 562-569.

Katz, L. G. (2010). STEM in the early years. SEED papers, Retrieved November, 3.

Kaya, H. İ. (2010). Öğretmen eğitiminde yapılandırmacı öğrenmeye dayalı uygulamaların öğretmen adaylarının problem çözme, eleştirel düşünme ve yaratıcı düşünme eğilimlerine etkileri. Yayımlanmamış doktora tezi, Atatürk Üniversitesi Sosyal Bilimler Enstitüsü, Erzurum.

Kaya, D. ve Gündüz, M. (2015). Alternatif eğitim ve toplumsal değişim üzerindeki etkisi: "Waldorf Okulları Örneği”. MEB Dergisi, 205. 
Knezek, G., Christensen, R., Tyler-Wood, T. and Periathiruvadi, S. (2013). Impact of environmental power monitoring activities on middle school student perceptions of STEM. Science Education International, 24(1), 98-123.

Korkmaz, Ö. (2009). Öğretmenlerin eleştirel düşünme eğilim ve düzeyleri. Ahi Evran Üniversitesi Kırşehir Eğitim Fakültesi Dergisi, 10(1), 1-13.

Koştur, H. İ. (2017). FeTeMM eğitiminde bilim tarihi uygulamaları: El-Cezerî Örneği. Journal Of Educatıon, 4(1), 61-73.

Koyunlu Ünlü, Z. ve Dere, Z. (2018) Okul Öncesi Öğretmen Adaylarının Hazırladıkları FeTeMM Etkinliklerinin Değerlendirilmesi. Ahi Evran Üniversitesi Kırşsehir Eğitim Fakültesi Dergisi, 19(2), 1502-1512.

Kökdemir, D. (2003). Belirsizlik durumlarında karar verme ve problem çözme. Yayımlanmamış doktora tezi,, Ankara Sosyal Bilimler Enstitüsü, Ankara.

Kuşçu, Ö., Bozdaş, Y. ve Yıldırım Doğru, S.S. (2014). Montessori eğitiminin çocuklarda sorumluluk alma, sırasını bekleme, başladığı işi bitirme becerisine etkisinin değerlendirilmesi. Değerler Ë̆itimi Dergisi, 12(27), 307-322.

Milli Eğitim Bakanlığı, (2016). STEM Eğitimi Raporu. Ankara: SESAM.

Oğuz V. ve Köksal Akyol, A. (2006). Çocuk Eğitiminde Montessori Yaklaşımı. Ç.Ü. Sosyal Bilimler Enstitüsü Dergisi, 15(1), 243-256.

Özdağ, S. A. (2014). Montessori metodu' nun eğitim mekânlarına yansıması üzerine kavramsal bir analiz. Yayımlanmamış yüksek lisans tezi, Karadeniz Teknik Üniversitesi Fen Bilimleri Enstitüsü, Trabzon.

Pekbay, C. (2017). Fen teknoloji mühendislik ve matematik etkinliklerinin ortaokul ögrencileri üzerindeki etkileri. Yayımlanmamış yüksek lisans tezi, Hacettepe Üniversitesi Eğitim Bilimleri Enstitüsü, Ankara.

Riskowski, J. L., Todd, C. D., Wee, B., Dark, M. ve Harbor, J. (2009). Exploring the Effectiveness of an Interdisciplinary Water Resources Engineering Module in an Eighth Grade Science Course. International Journal of Engineering Education, 25(1), 181-195.

Seong-Hwan, C., (2013). The Effect of robots in education based on STEAM. Journal of Korea Robotics Society, 8(1), 58-65.

Siew, N. M., Amir, N. and Chong, C. L. (2015). The Perceptions of Pre-Service and İn-Service Teachers Regarding A Project-Based STEM Approach to Teaching Science. Springer Plus, 4(8), 1-20.

Soylu, S. (2016). STEM Education in Early Childhood in Turkey. Journal of Educational and Instructional Studies in the World, 6, 38-47.

Sullivan, F. V. (2008). Robotics and science literacy: thinking skills, science process skills and systems understanding. Journal of Research in Science Teaching, 45(3), 373-394.

Sungur Gül, K. ve Marulcu, İ. (2014). Yöntem olarak mühendislik-dizayna ve ders materyali olarak legolara öğretmen ile öğretmen adaylarının bakış açılarının incelenmesi. Turkish Studies, 9(2), 761-786. 
Strong, M. G. (2013). Developing elementary math and science process skills through engineering design instruction. New York: Hofstra University.

Şahintürk, Ö. (2012). Montessori yönteminin okul öncesi dönemde öğrencilerin yaratıcı düşünmelerine etkisi. Yayımlanmamış yüksek lisans tezi, Zonguldak Karaelmas Üniversitesi Sosyal Bilimler Enstitüsü, Zonguldak.

Şahin, A., Adıgüzel, T. ve Acar, M.C. (2014). Fen, Teknoloji, Mühendislik ve Matematik İçerikli Okul Sonrası Etkinlikler ve Öğrenciler Üzerindeki Etkileri. Kuram ve Uygulamada Eğitim Bilimleri, 14(1), 297-322.

Tezel, Ö. ve Yaman, H. (2017). FeTeMM Eğitimine Yönelik Türkiye'de Yapılan Çalışmalardan Bir Derleme. Ë̆itim ve Öğretim Araştırmaları Dergisi,6(1), 135-145.

Uğraş, M. (2017). Okul Öncesi Öğretmenlerinin Stem Uygulamalarına Yönelik Görüşleri. Eğitimde Yeni Yaklaşım Dergisi, 1(1), 39-54.

Uyanık Balat, G. ve Günşen, G. (2017). Okul Öncesi Dönemde STEM Yaklaşımı. Akademik Sosyal Araştırmalar Dergisi, 5(42), 337-348.

Van Till, C.T., Van Der Vleuten, C.P.M. and Van Berkel, H.J.M. (1997). Problem based learning behavior: the impact of differences in problem-based learning style and activity on student' achievement. Annual Meeting of the American Educational Research Association, 24-28, Chicago, USA.

Venville, G., Walace, J., Rennie, L. and Malone, J. (2000). Bridging the boundaries of compartmentalized knowledge: student learning in an integrated environment. Research in Science and Technological Education, 18(1), 23-25.

Yaman S. ve Yalçın, N. (2005). Fen bilgisi öğretiminde probleme dayalı öğrenme yaklaşımının yaratıcı düşünme becerisine etkisi. İlköğretim-Online, 4(1), 42-52.

Y1ldırım, B. ve Selvi, M. (2016). Examination of the effects of STEM education integ-rated as a part of science, technology, society and environment courses. Journal of Human Sciences, 13(3), 3684-3695.

Yıldırım, B. ve Selvi, M. (2017). An experimental research on effects of STEM applications and mastery learning. Journal of Theory and Practice in Education, 13(2), 183-210.

Yıldırım, A., ve Şimşek, H. (2008). Sosyal bilimlerde nitel araştırma yöntemleri. (6.Baskı). Ankara: Seçkin Yayıncılık.

Yuvac1, Z. ve Dağlığlu, H.E. (2018). Okul öncesi eğitim alan çocukların ve bulundukları sınıf ortamının yaratıc1lık düzeyleri arasındaki ilişkisinin incelenmesi, Erken Çocukluk Çalışmaları Dergisi, 2(2), 234-256.

Wallas, G. (1926). The art of thought. New York, NY: Harcourt, Brace and Company

Whetton, D. A. and Cameron, K. S. (2002). Answers to exercises taken from developing management skills. 3rd Edition, Illlinois: Northwestern University. 